\title{
PERSEPSI MASYARAKAT TERHADAP GANGGUAN GAJAH SUMATERA (Elephas maximus sumatranus) DI KABUPATEN OGAN KOMERING ILIR
}

\author{
(The Perception of Community towards the Disturbance of Sumateran Elephant \\ (Elephas maximus sumatranus) in Ogan Komering Ilir Regency) \\ Anita Rianti dan R.Garsetiasih \\ Pusat Penelitian dan Pengembangan Hutan, \\ J1. Gunung Batu No. 5 Bogor, 16118, Indonesia \\ E-mail: nietha_21@yahoo.com; garsetiasih@yahoo.com
}

Diterima 2 Maret 2017, direvisi 23 Mei 2017, disetujui 5 Juni 2017

\begin{abstract}
Research of elephant conflict with community have been conducted in Sungai Menang District, Ogan Komering Ilir Regency, South Sumatera Province. This study was conducted in three villages in September through December 2015. This study aimed to identify the perception and socio-economic characteristics of the community related to the conflict towards elephant conservation value. Data was collected through structured interview, while respondents were selected intentionally (purposive sampling). The results are shown that the level of community education in the village of Gajah Mati dan Gajah Mulya are low, 51\% and 47\% respectively, which are elementary school graduates, while the level of education in the village of Gajah Mukti is 58\% of high school graduates. The majority of respondents are in productive age classes and worked as a farmer. The average income per month of people in the village of Gajah Mati is Rp1,814,583, while in Gajah Mukti and Gajah Mulya Village are Rp1,158,750 and Rp1,060,833 respectively. Elephants disturbance occur in all respondent villages and has an impact on the community perception of the elephant conservation becomes negative. Most respondents want that the elephants are relocated to Padang Sugihan Wildlife Sanctuary which is suitable for the habitat of the elephants.
\end{abstract}

Keywords: Elephant; perception; conservation; conflict; community.

\begin{abstract}
ABSTRAK
Penelitian konflik gajah dengan masyarakat telah dilakukan di Kecamatan Sungai Menang Kabupaten Ogan Komering Ilir, Provinsi Sumatera Selatan. Penelitian dilakukan di tiga desa pada bulan September 2015 sampai Desember 2015, dengan tujuan untuk mengetahui persepsi serta karakteristik sosial-ekonomi masyarakat terkait konflik terhadap nilai konservasi gajah. Pengumpulan data dilakukan dengan wawancara secara terstruktur, responden dipilih secara sengaja (purposive sampling). Hasil penelitian menunjukkan bahwa tingkat pendidikan masyarakat di Desa Gajah Mati dan Gajah Mulya masih rendah yaitu masing-masing 51\% dan 47\% merupakan lulusan SD, sedangkan tingkat pendidikan di Desa Gajah Mukti sebesar 58\% adalah lulusan SMA. Mayoritas responden termasuk dalam kelas usia produktif dan bekerja sebagai petani ladang. Pendapatan rata-rata masyarakat di Desa Gajah Mati sebesar Rp1.814.583 per bulan, sedangkan di Desa Gajah Mukti dan Gajah Mulya masingmasing secara berurutan adalah Rp1.158.750 dan Rp1.060.833. Gangguan gajah terjadi di semua desa responden, dan berdampak pada persepsi masyarakat terhadap konservasi gajah menjadi negatif. Sebagian besar responden menginginkan gajah dipindahkan ke Suaka Margasatwa Padang Sugihan yang merupakan habitat gajah.
\end{abstract}

Kata kunci: Gajah; persepsi; konservasi; konflik; masyarakat. 


\section{PENDAHULUAN}

Meningkatnya jumlah populasi manusia berdampak pada meluasnya pembangunan di berbagai sektor diantaranya pembukaan kawasan hutan untuk perkebunan dan pertambangan, menyebabkan konflik antara manusia dan satwa liar menjadi sering terjadi. Konflik antara manusia dan satwa liar terjadi akibat sejumlah interaksinegatif baik langsung maupun tidak langsung antara manusia dan satwa liar (Hariyanto, 2010). Pada kondisi tertentu konflik tersebut merugikan semua pihak diantaranya terjadi gangguan satwa liar yang menyebabkan kerusakan ladang masyarakat atau perusahaan perkebunan, dan sebaliknya satwa liar juga terancam oleh manusia (masyarakat). Gangguan satwa liar yang terjadi cenderung menimbulkan sikap negatif manusia terhadap satwa liar, yaitu berkurangnya apresiasi manusia terhadap satwa. Salah satu contoh dari sikap negatif yaitu terjadinya kematian tiga ekor gajah pada tahun 2013 di areal perkebunan yang berada di Kecamatan Sungai Menang Kabupaten Ogan Komering Ilir (OKI) Sumatera Selatan yang diduga disebabkan oleh racun (PT. Sampoerna Agro, 2013).

Konflik antara masyarakat dan gajah merupakan konflik yang sering terjadi dan mengancam keberadaan gajah. Gajah salah satu jenis satwa yang mendapatkan pakannya sebagian besar dari dalam kawasan hutan. Gajah sangat membutuhkan keberadaan hutan sebagai tempat hidup dan berkembang biak. Deforestasi yang terus menerus terjadi semakin mengancam kehidupan satwa liar termasuk gajah sumatera yang habitatnya terus mengalami kerusakan baik penyempitan maupun fragmentasi, akibat adanya konversi hutan menjadi perkebunan dan hutan tanaman industri. Yoza (2003) menyatakan bahwa perkebunan kelapa sawit dan Hutan Tanaman Industri (HTI) merupakan salah satu penyebab berkurangnya tutupan hutan dan terjadinya fragmentasi habitat.
Pengelolaan konflik sektor kehutanan perlu dijadikan pembelajaran bagi semua pihak, sudah saatnya pihak pemerintah memerhatikan pengelolaan konflik sebagai salah satu persyaratan dalam pengelolaan hutan (Wulan, Yasmi, Purba, \& Wollenberg, 2004). Berbagai upaya penanggulangan dan penanganan konflik manusia dan gajah sumatera telah dilakukan, baik oleh pemerintah maupun masyarakat, namun belum efektif. Oleh sebab itu, diperlukan suatu solusi dalam mengurangi konflik manusia dan gajah sumatera yang sesuai dengan kondisi sosial ekonomi masyarakat sekitar hutan dan perkebunan dimana gajah beraktivitas. Hasil penelitian Garsetiasih (2015) menunjukkan bahwa persepsi masyarakat terhadap satwa liar diantaranya dipengaruhi oleh tingkat pendidikan. Tingkat pendidikan yang rendah mempersepsikan negatif terhadap keberadaan satwa liar. Penelitian ini bertujuan untuk mengetahui persepsi dan karakteristik sosial ekonomi masyarakat sekitar kawasan hutan dan perkebunan terhadap konservasi gajah sumatera (Elephas maximus sumatranus Temminck, 1847). Hasil penelitian diharapkan dapat dijadikan acuan dalam pengambilan keputusan pengelolaan gajah dan mengurangi terjadinya konflik antara masyarakat dengan gajah sumatera.

\section{METODE PENELITIAN}

\section{A. Waktu dan Lokasi Penelitian}

Penelitian dilakukan pada bulan September 2015 sampai dengan Desember 2015. Lokasi penelitian di sekitar kawasan hutan dan perkebunan PT. Selatan Jaya Permai (PT. SJP), PT. Sampoerna Agro, Tbk., PT. Russelindo Putra Prima (RPP), PT. Bumi Mekar Hijau (BMH), Kecamatan Sungai Menang, Kabupaten Ogan Komering Ilir (OKI), Provinsi Sumatera Selatan. Desa-desa yang dijadikan lokasi penelitian adalah Desa Gajah Mati, Desa Gajah Mukti dan Desa Gajah Mulya. Desa-desa tersebut letaknya 
berbatasan langsung dengan kawasan hutan dan areal perkebunan dan lahan pertanian masyarakatnya mendapat gangguan gajah.

\section{B. Bahan dan Alat Penelitian}

Bahan dan alat yang digunakan dalam penelitian ini adalah kawasan hutan yang merupakan habitat gajah, masyarakat sekitar kawasan hutan dan perkebunan, perusahaan yang mendapat gangguan gajah, perusahaan Hutan Tanaman Industri (HTI), panduan wawancara (kuesioner), alat tulis, kompas, Global Positioning System (GPS), peta kerja, dan kamera.

\section{Metode Penelitian}

\section{Pengumpulan data}

Pengumpulan data sosial dan ekonomi serta persepsi masyarakat sekitar kawasan hutan dilakukan melalui wawancara dengan menggunakan kuesioner. Panduan wawancara meliputi umur, tingkat pendidikan, tingkat pendapatan, jenis pekerjaan, jenis tanaman dan produktivitasnya, pola tanam, pola pemanfaatan lahan dan luasan lahan. Responden ditentukan secara purposive sampling dari kelompok dan anggota masyarakat yang terganggu dengan kehadiran gajah. Untuk mengetahui persepsi masyarakat terhadap konservasi gajah dan keberadaan hutan dilakukan melalui wawancara secara terstruktur dengan daftar pertanyaan yang telah disiapkan sebelumnya.

\section{Analisis data}

Data hasil penelitian berdasarkan wawancara dan pengamatan ditabulasi dan dinilai berdasarkan persentase dan disajikan dalam grafik dan tabel. Data hasil pengolahan dengan piranti lunak Microsoft Excel dianalisis dan diinterpretasikan secara deskriptif kuantitatif.

\section{HASIL DAN PEMBAHASAN}

\section{A. Karakteristik Gajah}

Gajah sumatera (Elephas maximus sumatranus Temminck, 1847) merupakan salah satu kekayaan fauna Indonesia dan termasuk satwa langka berdasarkan UndangUndang (UU) Nomor 5 Tahun 1990 Tentang Konservasi Sumber Daya Alam Hayati dan Ekosistem, sehingga keberadaan gajah dilindungi dan perlu dilestarikan (Riba'i, Setiawan, \& Darmawan, 2013). Gajah sumatera hanya ditemukan di Sumatera dan Kalimantan bagian timur. CITES (Convention on International Trade of Endangered Fauna and Flora/Konvensi tentang Perdagangan Internasional Satwa dan Tumbuhan) mengkategorikan gajah asia dalam kelompok Appendix I dan terdaftar dalam red listbook IUCN (The World Conservation Union), dengan status terancam punah (IUCN, 2011).

Populasi gajah sumatera saat ini mengalami penurunan dan terancam kepunahan. Populasi tahun 2003 tercatat sebanyak 354-431 individu (Unit KSDA Riau, 2010). Tahun 2005 diperkirakan di Bengkalis Riau menjadi 35-50 individu dan tahun 2009 menurun menjadi 34 individu (Suhandri, Sukamtoro, Samsuardi, Rusiano, \& Yulianto, 2011). Pada saat penelitian tahun 2015 hanya dijumpai 1-16 individu di wilayah perkebunan Kecamatan Sungai Menang, Kabupaten Ogan Komering Ilir, Sumatera Selatan (Garsetiasih, Rianti, \& Eman, 2015). Hamid (2001) menyatakan bahwa penurunan populasi gajah diakibatkan adanya penyusutan habitat yang tersedia, sehingga tidak mampu menampung populasi gajah. Penurunan populasi juga disebabkan oleh rendahnya kualitas habitat dan terjadinya konflik gajah dengan manusia (WWF \& BKSDA Provinsi Riau, 2010).

Habitat gajah sumatera yaitu di hutan tropis dataran rendah dan rawa-rawa sampai ketinggian 1.000 meter di atas permukaan laut (Saleh dan Adriani, 2005). Salah satu habitat endemik gajah sumatera yaitu di Taman Nasional Way Kambas (TNWK) (Syarifuddin, 2008).

Hedges et al. (2002) menyatakan gajah melakukan aktivitas hariannya di hutan primer seperti interaksi sosial, menghindar dari musuh, reproduksi, dan aktivitas makan. 
Seidenticker (1984) menyatakan bahwa gajah sumatera membutuhkan hutan primer sebagai tempat bernaung dan beristirahat. Gajah sumatera biasa menghabiskan waktu di hutan sekunder dan padang rumput untuk makan dan berjalan. Secara umum, gajah asia lebih sering berada di hutan primer untuk beraktivitas (Chen, Deng, Zhang, \& Bai, 2006).

Gajah biasanya beristirahat dua kali sehari, yaitu pada tengah malam dan siang hari. Pada malam hari, gajah sering tidur merebahkan diri ke samping tubuhnya di hutan primer, sedangkan pada siang hari, gajah beristirahat sambil berdiri di bawah pohon rindang. Pada siang hari, apabila kondisi lingkungan kurang aman, gajah akan memilih tidur sambil berdiri yang berfungsi sebagai perilaku siaga terhadap munculnya gangguan. Waktu istirahat biasanya dimanfaatkan untuk berkubang dan menggesekkan badan ke pohon. Pada musim kawin, gajah jantan akan memanfaatkan waktu istirahatnya untuk menarik perhatian gajah betina (Sukumar, 1989).

Gajah sumatera membutuhkan jumlah konsumsi pakan yang banyak untuk mencukupi kebutuhan energi sesuai dengan ukuran tubuhnya yang besar (Seidenticker, 1984). Abdullah (2009) menyatakan bahwa jika kebutuhan pakan gajah yang tinggi tidak lagi terpenuhi oleh habitat, sementara potensi pakan yang tinggi tersedia di sekitar habitat, maka akan mendorong gajah untuk keluar dari habitatnya dan memanfaatkan sumber pakan yang tersedia di kawasan budidaya untuk memenuhi kekurangan pakan. Seidenticker (1984), menyatakan bahwa ketika habitat gajah tidak lagi sesuai dengan kebutuhannya, maka hewan ini akan keluar dari habitat menuju kawasan di sekitarnya antara lain perkebunan, perladangan atau pemukiman penduduk sehingga menimbulkan konflik dengan manusia. Selanjutnya Alikodra (1990), menyatakan bahwa ketika kondisi habitat rusak, gajah sumatera akan melakukan aktivitas untuk mendapatkan makanan dan cover dengan mencari hutan lain yang lebih baik dan lebih luas, seperti areal perkebunan, areal budidaya pertanian dan perladangan. Menurut Jogasara (2011), perubahan habitat gajah menjadi perkebunan monokultur (sawit dan karet) menyebabkan pengurangan habitat gajah secara nyata. Hal ini mengakibatkan gajah terperangkap dalam blok-blok kecil hutan yang tidak cukup untuk mendukung kehidupannya dalam jangka panjang, sehingga menjadi pemicu terjadinya konflik antara manusia dengan gajah. Hal ini terjadi di kawasan hutan dan perkebunan milik PT. Sampoerna Agro, Tbk, PT. Bumi Mekar Hijau (PT. BMH), dan PT. Russelindo Putra Prima (PT. RPP) yang ada di Kabupaten Ogan Komering Ilir. Gajah merusak tanaman sawit, karet, akasia, padi, dan tanaman pertanian lainnya milik masyarakat dan perusahaan.

\section{B. Karakteristik Masyarakat sekitar Kawasan Perkebunan yang Mendapat Gangguan Gajah}

Penelitian terhadap kondisi sosial ekonomi serta persepsi masyarakat terhadap konservasi gajah dan keberadaan perusahaan perkebunan maupun perusahaan HTI dilakukan pada masyarakat yang letak desanya di sekitar kawasan perkebunan dan lahan pertaniannya mendapat gangguan gajah. Desa-desa yang dijadikan sampel penelitian yaitu Desa Gajah Mati, Desa Gajah Mukti, dan Desa Gajah Mulya. Hasil pengamatan karakteristik sosial ekonomi masyarakat sekitar kawasan hutan yang berbatasan dengan perkebunan disajikan pada Tabel 1.

Pada Tabel 1 menunjukkan bahwa sebagian besar responden di ketiga desa yang dijadikan sampel penelitian masuk dalam kategori umur produktif. Hamid, Zulkarnaini, \& Saam (2011) menyatakan bahwa usia produktif adalah usia yang berada diatas 10 tahun dan kurang dari 50 tahun, sehingga masih produktif untuk bekerja. Responden masyarakat dalam umur produktif sangat berpotensi untuk melakukan pekerjaan dengan maksimal, memiliki semangat tinggi dan cukup kreatif mencari berbagai usaha 
Tabel 1. Karakteristik responden di tiga desa sekitar kawasan perkebunan PT. Sampoerna Agro, PT. Russelindo Prima Putra dan PT. Bumi Mekar Hijau

Table 1. Characteristics of respondent in the three villages around the plantation area of PT. Sampoerna Agro, PT. Russelindo Prima Putra and PT. Bumi Mekar Hijau

\begin{tabular}{|c|c|c|c|}
\hline \multirow[b]{2}{*}{ Indikator (Indicator) } & \multicolumn{3}{|c|}{$\begin{array}{l}\text { Persentase jumlah responden (\%) } \\
\text { (Percentage of total of respondent) }\end{array}$} \\
\hline & $\begin{array}{c}\text { Desa Gajah } \\
\text { Mati(Gajah Mati } \\
\text { Village) }\end{array}$ & $\begin{array}{c}\text { Desa Gajah } \\
\text { Mukti (Gajah } \\
\text { Mukti Village) }\end{array}$ & $\begin{array}{c}\text { Desa Gajah Mulya } \\
\text { (Gajah Mulya } \\
\text { Village) }\end{array}$ \\
\hline \multicolumn{4}{|l|}{$\begin{array}{l}\text { Kelas Umur/tahun (Age of Class/ } \\
\text { years) }\end{array}$} \\
\hline - $20-29$ & 12 & - & 18 \\
\hline - 30-39 & 32 & 26 & 12 \\
\hline - 40-49 & 17 & 47 & 53 \\
\hline - $50-59$ & 20 & 16 & 6 \\
\hline - $60-69$ & 14 & 11 & 12 \\
\hline \multicolumn{4}{|l|}{ Pendidikan (Education) } \\
\hline - Tidak sekolah (Do not school) & - & - & 6 \\
\hline - SD (Elementary school) & 51 & 32 & 47 \\
\hline - SMP (Junior school) & 28 & 5 & 29 \\
\hline - SMA (High school) & 21 & 58 & 18 \\
\hline - Diploma (Bachelor) & - & 5 & - \\
\hline \multicolumn{4}{|l|}{ Pekerjaan utama $(\mathrm{Job})$} \\
\hline - Petani(Farmer) & 70,8 & 42,1 & 70,6 \\
\hline
\end{tabular}

Sumber (Source): Data primer (Primary data)

untuk menghasilkan pendapatan dalam rangka memenuhi kebutuhan hidup keluarga.

Tingkat pendidikan responden di Desa Gajah Mati dan Desa Gajah Mulya termasuk kategori rendah karena sebanyak $51 \%$ dan $47 \%$ responden hanya tamat SD, sedangkan di Desa Gajah Mukti sebanyak 58\% responden tamat SMA. Rendahnya tingkat pendidikan di Desa Gajah mati dan Gajah Mulya, menyebabkan masyarakat tidak memiliki peluang untuk mendapatkan pekerjaan yang memadai, sehingga sebagian besar responden hanya bekerja sebagai petani. Masyarakat yang sebagian besarnya berprofesi sebagai petani cenderung sangat bergantung pada sumber daya lahan yang ada di sekitarnya dalam memenuhi kebutuhan hidupnya (Kadir, Nurhaedah, \& Purwanti, 2013).
Tingkat pendidikan responden di Desa Gajah Mukti sebagian besar tamat SMA, sehingga jenis pekerjaannya lebih beragam selain sebagai petani dan buruh perkebunan $(42,1 \%)$, ada juga yang berprofesi sebagai guru dan bidan. Responden di Desa Gajah Mati dan Desa Gajah Mulya umumnya bermata pencaharian sebagai petani, yaitu masing-masing $70,8 \%$ dan $70,6 \%$, sedangkan responden yang memiliki mata pencaharian petani di Desa Gajah Mukti hanya 42,1\%.

Tingkat pendidikan masyarakat yang rendah disebabkan oleh sarana pendidikan yang kurang memadai, hal ini terlihat dari terbatasnya sarana pendidikan yang ada di desa yaitu lokasi masing-masing desa yang menyebar dengan konsentrasi penduduk yang kecil, jumlah sekolah dan guru yang terbatas, 
dan sekolah lanjutan tingkat pertama dan atas yang hanya berada di pusat kecamatan dengan jumlah yang terbatas. Pada tiga desa responden, tidak semua desa memiliki tenaga pendidik, tenaga pendidik yang berijazah diploma hanya terdapat di Desa Gajah Mukti.

Tingkat pendidikan yang rendah menyebabkan pemahaman dan persepsi terhadap konservasi gajah menjadi sangat rendah (Garsetiasih, 2015). Tingkat pendidikan formal mempunyai peran penting dalam membentuk pola pikir masyarakat dalam bertindak. Masyarakat dengan tingkat pendidikan rendah sulit untuk menerima halhal baru atau inovasi yang dapat menambah wawasan, pengalaman, dan pengetahuan (Kadir, 2005). Tingkat pendidikan yang rendah berpengaruh terhadap pemahaman masyarakat pada konservasi satwa liar karena cara pandang serta keterbatasan pengetahuan yang dimiliki (Garsetiasih, 2015). Hal ini dimungkinkan menjadi faktor pendorong yang kuat bagi masyarakat sekitar kawasan untuk melakukan tekanan berupa pemanfaatan sumber daya hutan, terutama masyarakat yang mempunyai ketergantungan hidup dengan kawasan (Alikodra, 1987). Nurlita dan Mamonto (2012) menyatakan bahwa tingkat pendidikan yang rendah juga sangat berhubungan erat dengan persepsi masyarakat terhadap sumber daya hutan. Pendidikan yang rendah menyebabkan terbatasnya pilihan mata pencaharian selain sebagai petani atau buruh tani untuk memenuhi kebutuhan harian, sehingga masyarakat terpaksa memanfaatkan sumber daya yang ada di sekitarnya. Kadir, Awang, Purwanti, \& Poedjirahajoe (2012) menyatakan bahwa tingkat pendidikan yang rendah menjadikan masyarakat tidak punya pilihan pekerjaan lain kecuali bekerja sebagai petani.

Tingkat pendidikan yang rendah juga dapat menyebabkan standar kemiskinan semakin rendah dan jauh dari kategori sejahtera (Berliani, Alikodra, Masy'ud, \& Kusrini, 2016b). Tingkat pendidikan masyarakat rendah, makatingkatkesejahteraan masyarakat juga rendah, karena tingkat pendidikan berhubungan dengan pendapatan masyarakat (Hamid et al., 2011). Untuk mengatasi kondisi tingkat pendidikan yang rendah dengan pengetahuan yang minim dibutuhkan tambahan pengetahuan dan informasi melalui kegiatan penyuluhan, sosialisasi aturanaturan, pelatihan dan program konservasi, serta melakukan kegiatan pendampingan bagi masyarakat sekitar kawasan perkebunan dalam meningkatkan hasil pertaniannya maupun ilmu pengetahuan lainnya.

\section{Tingkat Pendapatan Masyarakat}

Jenis tanaman yang dikembangkan oleh mayoritas responden masyarakat di tiga desa terdiri atas tanaman perkebunan dan pertanian yaitu karet (Hevea brasiliensis), sawit (Elaeis guineensis), singkong (Manihot utilissima), padi (Oryza sativa), dan kelapa (Cocos nucifera) (Tabel 2). Dari ketiga desa responden, mayoritas responden memanfaatkan jenis tanaman hutan alam yaitu gelam (Melaleuca leucadendra).

Pemilihan jenis komoditas didasarkan pada pertimbangan dari aspek waktu dan kemudahan pemanenan. Karet dan sawit dapat dipanen dalam waktu yang lama dan hasil panen dapat langsung dijual ke perusahaan perkebunan yang lokasinya berdekatan dengan kebun masyarakat. Tanaman padi dapat dipanen setahun dua kali, singkong dan kelapa merupakan jenis tanaman tambahan yang dikembangkan, yang diharapkan dapat menambah penghasilan untuk memenuhi kebutuhan sehari-hari. Pemanfaatan kayu gelam dilakukan untuk pemenuhan akan kayu bakar, perbaikan rumah, dan diperjualbelikan secara komersil. Hanya Desa Gajah Mulya, yang masyarakatnya sering berburu burung truwuk untuk konsumsi sehari-hari dan diperjualbelikan dalam bentuk burung potong. Pendapatan masyarakat dari hasil perkebunan dan pertanian yang diusahakan di Desa Gajah Mati, Desa Gajah Mukti dan Desa Gajah Mulya disajikan pada Tabel 2. 


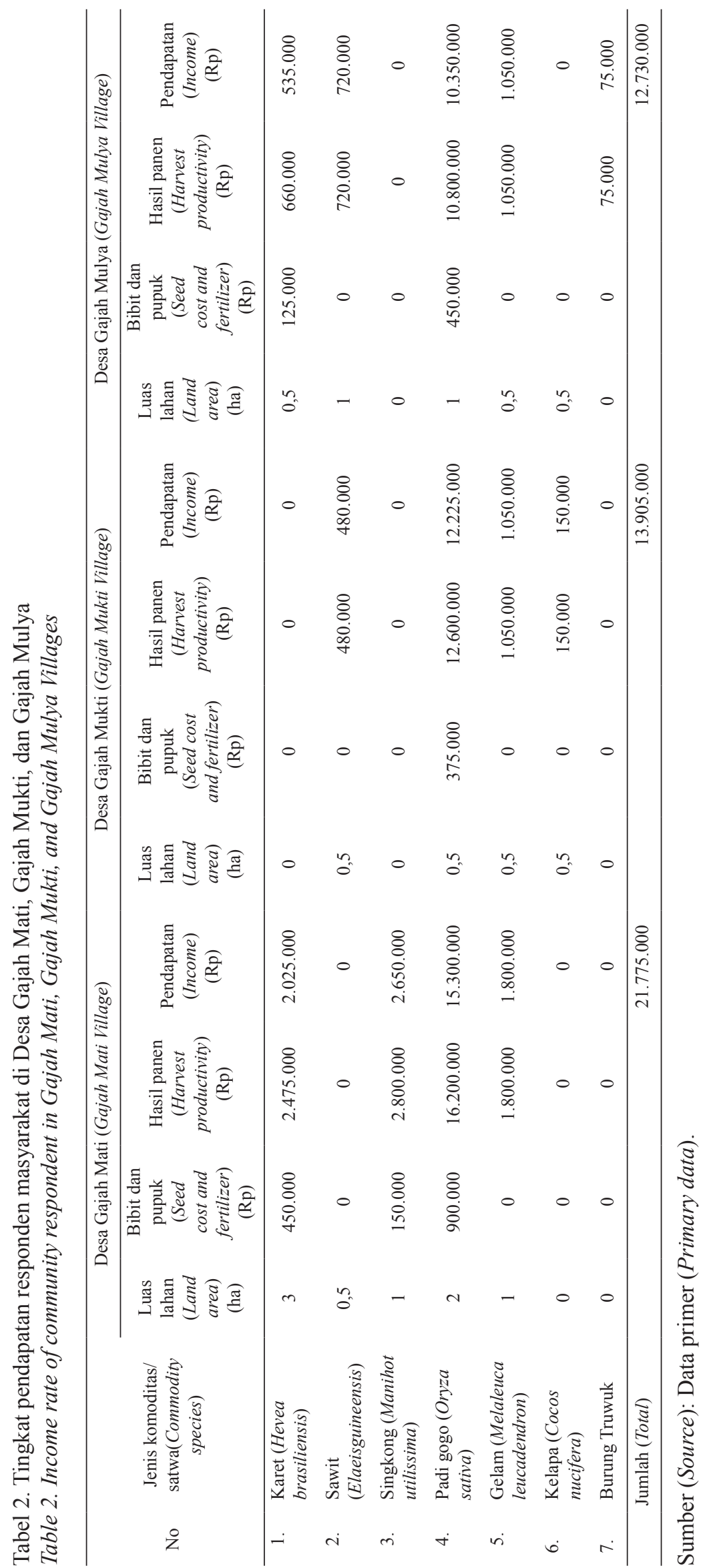


Hasil penelitian menunjukkan bahwa umumnya responden di tiga desa merupakan masyarakat transmigrasi yang memiliki luas lahan garapan dengan kisaran 0,5-3 ha.Luas kepemilikan lahan memiliki hubungan yang nyata dengan aspek sosial ekonomi masyarakat. Semakin luas kepemilikan lahan maka semakin sejahtera kondisi sosial ekonomi masyarakat tersebut (Hamid et al., 2011). Lahan garapan padi dan perkebunan karet di Desa Gajah Mati relatif lebih luas dibanding desa lainnya. Rata-rata luas garapan masyarakat di Desa Gajah Mati untuk komoditas padi seluas dua hektar dengan hasil panen rata-rata 1,8 ton per hektar per sekali panen dan kebun karet seluas tiga hektar dengan hasil panen rata-rata $15 \mathrm{~kg}$ per hari, sedangkan rata-rata luas lahan garapan masyarakat di Desa Gajah Mulya dan Desa Gajah Mukti rata-rata hanya berkisar 0,5-1 ha untuk komoditas padi dan 0,5 ha untuk kebun karet.

Perhitungan produksi tanaman yang dikembangkan masyarakat di sekitar perkebunan yang tertinggi adalah di Desa Gajah Mati sebesar Rp21.775.000 atau sebesar Rp1.814.583 per bulan, dan pemasukan terbesar berasal dari hasil panen padi. Pendapatan masyarakat per bulan ratarata di Desa Gajah Mukti dan Desa Gajah Mulya berturut-turut adalah Rp1.158.750 dan Rp1.060.833. Pendapatan ini relatif lebih rendah jika dibandingkan dengan upah minimum regional Kabupaten OKI tahun 2014 Rp1.826.000 (Badan Pusat Statistik, 2014). Beberapa faktor yang menyebabkan rendahnya pendapatan masyarakat yaitu adanya pengeluaran untuk pembelian bibit, pupuk dan pestisida, serta luas lahan garapan yang kecil. Selain itu, adanya beban biaya tambahan untuk pengangkutan hasil panen karena jarak tempuh dari lokasi perkebunan dan desa yang cukup jauh. Faktor lainnya adalah belum optimalnya penggunaan pola tanam dan pemeliharaan.

Hasil dari kelapa sawit belum terlalu dirasakan oleh masyarakat, hal ini dikarenakan masyarakat belum melakukan pemeliharaan yang intensif, sehingga produksinya masih rendah. Rifa'i, Hadi, \& Qomar, (2008) menyatakan bahwa komoditas kelapa sawit, produktivitasnya dipengaruhi oleh penggunaan bibit unggul dan pemeliharaannya. Mursidah (2009), menyatakan bahwa tingkat optimal pendapatan akan tercapai bila penggunaan faktor-faktor produksi telah efisien dan harga yang berlaku dapat menjamin, sehingga produksi yang diperoleh mencerminkan tingkat efisiensi hasil usahataninya.

\section{Ketergantungan Masyarakat pada Sumber Daya Hutan}

Manusia dan hutan memiliki hubungan yang unik, dimana manusia merupakan bagian dari ekosistem itu sendiri. Hubungan timbal balik antara manusia dan hutan merupakan interaksi yang saling memengaruhi. Jika hutan rusak, maka kehidupan manusia akan terancam, dan sebaliknya jika manusia terpenuhi kesejahteraannya kelestarian hutan pun dapat terjaga (Nurrani dan Tabba, 2013).

Kehidupan masyarakat di tiga desa sekitar kawasan hutan yang berbatasan dengan areal perkebunan, masih dipengaruhi oleh kondisi hutan di sekitarnya, baik secara langsung dan tidak langsung. Ketergantungan masyarakat terhadap hutan yaitu memanfaatkan hutan dengan berbagai kegiatan. Kegiatan yang sering dilakukan adalah mencari kayu gelam, madu, kayu bakar, buah, jamur, dan burung truwuk (Gambar 1). Ketergantungan masyarakat di tiga desa responden terhadap kayu sangat besar bagi pemenuhan kebutuhan hidup. Desa Gajah Mulya sebagian besar respondennya $(47,1 \%)$ mencari kayu gelam. Berdasarkan hasil wawancara, pemanfaatan kayu gelam oleh masyarakat terbagi menjadi empat yaitu untuk bahan bangunan, bahan pembuatan perkakas rumah tangga, bahan bakar, dan bahan untuk diperjualbelikan (komersial), dimana hasilnya digunakan untuk memenuhi kebutuhan hidup sehari-hari.

Pemanfaatan kayu bakar dari dalam 


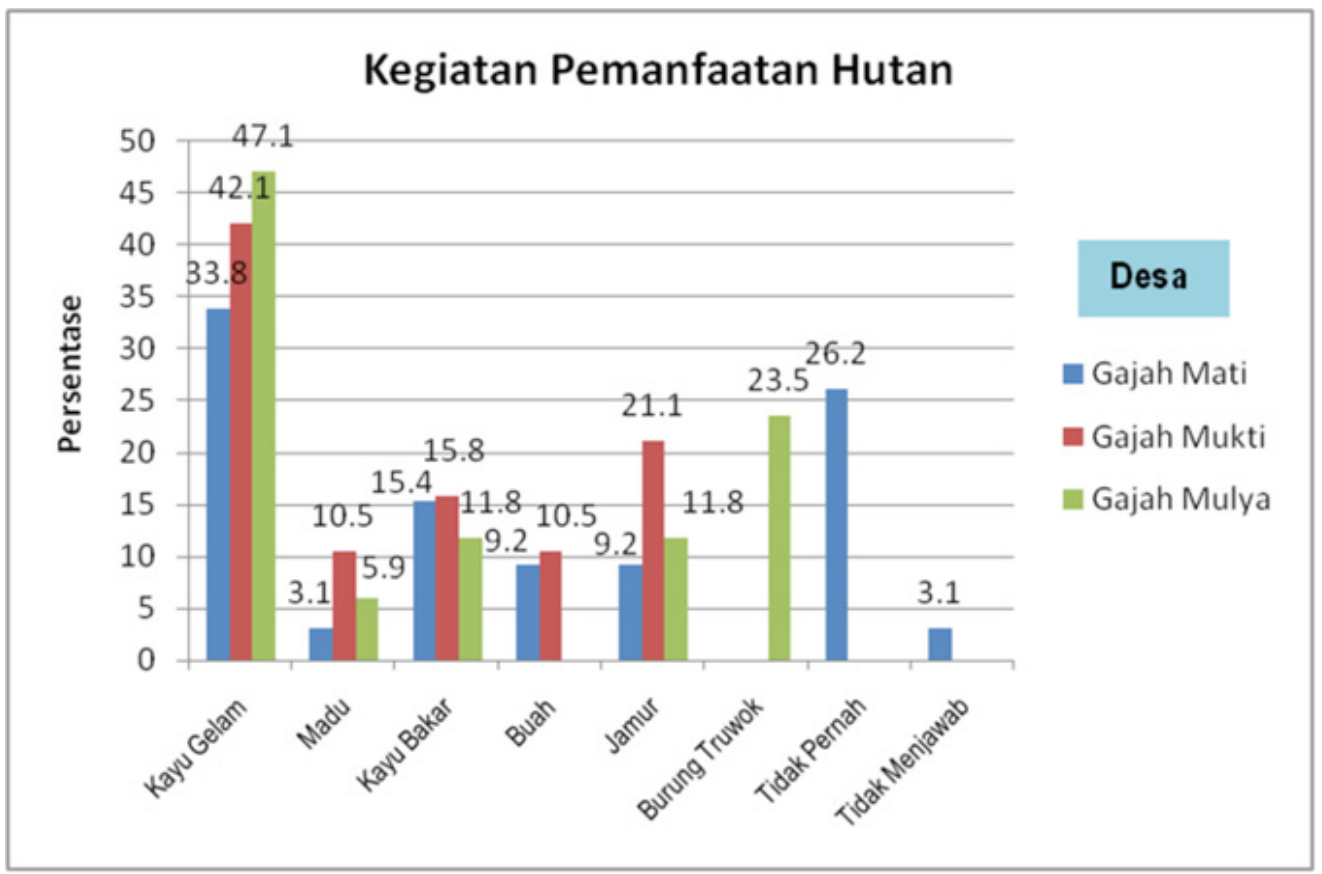

Sumber (Source): Data primer (Primary data)

\section{Gambar 1.Kegiatan pemanfaatan hutan}

Figure 1. Forest utility activity

kawasan hutan tertinggi adalah sebanyak 15,8\% berasal dari Desa Gajah Mukti. Cara hidup tradisional masih banyak dilakukan oleh responden. Mahalnya harga bahan bakar minyak dan gas, sulitnya akses jalan dan alat transportasi yang terbatas, dimungkinkan menjadi penyebab melambatnya proses pendistribusian bahan bakar minyak dan gas, sehingga masyarakat lebih memilih menggunakan kayu bakar. Kebutuhan kayu bakar dipenuhi dari pengambilan kayu gelam, ranting, cabang dan batang pohon kering dari dalam hutan, kebun-kebun masyarakat ataupun dari kawasan perkebunan. Awang (2006) menyatakan bahwa masyarakat di sekitar hutan pada umumnya memiliki ketergantungan yang sangat tinggi terhadap sumber daya alam hutan yang ada di sekitarnya yang ditandai dengan eratnya hubungan mereka dengan alam sekitar.

Ketergantungan masyarakat akan hasil hutan bukan kayu (HHBK) seperti jamur, burung truwuk, buah-buahan, dan madu juga sangat tinggi (Gambar 1). Desa Gajah Mukti sebagian besar masyarakatnya mencari jamur di hutan (22,2\%). Masyarakat juga memanfaatkan hutan untuk mengambil jamur yang ada di hutan gelam, untuk dikonsumsi sehari-hari, jika keberadaan jamur melimpah sebagian jamur yang dikumpulkan dijual, namun berdasarkan wawancara mayoritas responden menyatakan bahwa jamur tidak dapat dimasukan dalam pemasukan tetap bagi keluarga. Nurrani dan Tabba (2013), menyatakan bahwa sumber daya hutan yang dimanfaatkan masyarakat dapat dikelompokkan menjadi dua kategori antara lain; (a) Produktif, yaitu diperjualbelikan di pasar, dan (b). Konsumtif, yaitu yang dikonsumsi sendiri atau tidak dijual.

\section{E. Persepsi Responden terhadap Gangguan Satwa, Manfaat Kawasan Hutan, Gajah dan Perkebunan}

1. Persepsi responden terhadap gangguan satwa

Berdasarkan hasil wawancara, pada tiga desa responden, 100\% masyarakat responden menyatakan pernah diganggu oleh satwa. Responden menyatakan gangguan satwa 
sering terjadi pada kegiatan pertanian dan perkebunan yang dilakukan. Jenis satwa pengganggu yang merusak komoditas tanaman pertanian dan perkebunan yang diusahakan oleh masyarakat adalah babi hutan, gajah, monyet, musang, burung perkutut dan tikus. Satwa dengan intensitas gangguan tertinggi yaitu babi hutan $(47,7 \%)$ dan gajah $(24,6 \%)$, walaupun intensitas gangguan gajah lebih rendah tetapi tingkat kerusakan yang ditimbulkan lebih besar. Hal ini disebabkan dalam sekali gangguan gajah dapat merusak semua komoditas yang masyarakat tanam/usahakan. Masyarakat takut dan sulit menghindar dari gangguan gajah, hampir semua responden di tiga desa sampel mendapat gangguan gajah dan merasa bahwa gajah merupakan satwa yang merugikan dan tidak bermanfaat. Walaupun tidak bermanfaat, tetapi masyarakat mengaku tidak melakukan serangan terhadap gajah yang mengganggu tanaman mereka. Ketika menjelang musim panen, masyarakat hanya menjaga dan mengusir gajah yang datang pada saat menjelang musim panen.

Febriani (2009) menyatakan bahwa daerah yang dahulunya merupakan kawasan gajah atau wilayah jelajah gajah berpotensi besar untuk terjadinya konflik gajah dengan manusia, karena pada daerah tersebut, saat ini telah dijadikan pemukiman, lahan pertanian dan perkebunan, baik oleh masyarakat maupun oleh perusahaan. Yoza (2009) menyatakan bahwa gangguan gajah atau konflik gajah dan manusia tertinggi banyak terjadi pada ruangruang yang digunakan bersama oleh manusia dan gajah. Kasus tersebut banyak terjadi di lahan-lahan yang dikonversi dari hutan menjadi kebun sawit.

Gangguan gajah dapat juga terjadi karena tanaman yang diusahakan petani merupakan jenis yang disukai gajah. Tanaman pertanian dan perkebunan yang diusahakan oleh sebagian besar responden yaitu padi, karet, sawit, jagung dan singkong. Tanaman padi $(55,4 \%)$ merupakan jenis komoditas yang paling sering mendapat gangguan satwa, tanaman lainnya adalah singkong dan karet. Gangguan gajah pada tanaman pertanian dan perkebunan masyarakat, disebabkan habitat dan daerah jelajah gajah berbatasan langsung dengan ladang masyarakat, dan jenis komoditas yang ditanam oleh masyarakat merupakan beberapa jenis pakan yang disukai gajah. Berliani, Alikodra, Masy'ud, \& Kusrini (2016c), menyatakan bahwa dalam perilaku pemilihan pakan, gajah paling sering menunjukkan perilaku memilih tanaman padi. Jogasara (2011), menyatakan selain tanaman padi dan karet, gajah menyukai kelapa sawit yang masih muda berkisar umum dua tahun. Gangguan pada kelapa sawit akan berkurang bila umur kelapa sawit sudah lebih dari 2 tahun, hal ini dikarenakan gajah akan kesulitan untuk membongkar mahkota pohon kelapa sawit yang telah banyak durinya. Riba'i, Setiawan, \& Darmawan (2013), menyatakan bahwa jika dilihat dari kelompok tumbuhan, gajah sumatera menyukai jenis pakan dari kelompok rumput-rumputan dan palem. Harahap, Pratana, \& Afifuddin (2012), menyatakan bahwa tingkat kesukaan (palatability) satwa liar terhadap suatu jenis tanaman merupakan salah satu faktor yang dapat menyebabkan konflik satwa liar dengan masyarakat petani, sehingga dalam memilih komoditas perlu diupayakan yang tidak disukai oleh gajah. Jenis pakan yang tidak disukai gajah diantaranya kopi, coklat, kemiri, cabe dan tanaman nilam (Berliani, Alikodra, Masy'ud, \& Kusrini, 2016a).

Daerah jelajah gajah biasanya mengikuti ketersediaan pakan, tempat berlindung, dan berkembang biak. Gajah sering melintasi hutan tanaman akasia dan melakukan aktivitas harian seperti istirahat, sedangkan untuk memenuhikebutuhan pakan, gajah mendatangi kebun milik perusahaan perkebunan dan ladang masyarakat. Responden menyatakan kedatangan gajah menyebabkan kerusakan pada lahan pertanian dan kebun mereka. Menurut Garsetiasih (2012), gangguan satwa liar pada tanaman pertanian dan perkebunan disebabkan karena kurang tersedianya pakan 
di dalam kawasan hutan.

Suhartono et al. (2007) dalam Strategi dan Rencana Aksi Departemen Kehutanan RI (2007), menyebutkan bahwa ada tiga tingkatan gangguan satwa liar yang dikategorikan ringan, sedang, dan berat. Katagori gangguan ringan apabila satwa liar hanya melintas saja di pemukiman penduduk, dan tidak mengganggu. Jika satwa tersebut memakan tanaman dalam jumlah sedikit dan tidak menetap lebih dari satu hari. Kategori gangguan sedang, jika satwa liar tersebut menetap lama 1 (satu) sampai 3 (tiga) hari, kemudian memakan tanaman pertanian dalam jumlah besar dan mengganggu, tetapi tidak membunuh, sedangkan gangguan dikategorikan berat apabila satwa liar tersebut mengganggu masyarakat, memakan tanaman dan hewan ternak yang menyebabkan kerugian besar, merusak rumah dan pagar, bahkan membunuh.

Dampak konflik manusia dengan gajah sering menimbulkan kerugian baik dari pihak manusia maupun gajah. Kerugian yang dialami manusia dapat berupa kerugian harta dan jiwa. Kerugian harta seperti rusaknya kebun, tanaman pertanian, rumah, ternak dan lain-lain. Kerugian jiwa seperti adanya luka, cacat fisik maupun kematian. Dampak konflik terhadap gajah antara lain, kematian, pengusiran dan juga cacat fisik (Nuryasin, Yoza, \& Kausar, 2014). Berdasarkan hasil wawancara responden diketahui bahwa kerugian rata-rata yang dialami oleh masyarakat sekitar Rp7.000.000-Rp8.000.000 per satu kali kedatangan gajah pada lahan garapan pertanian dan perkebunan. Gangguan gajah di sekitar areal perkebunan dan pertanian masyarakat dapat dikategorikan gangguan sedang, karena masyarakat dirugikan oleh kehadiran gajah yang merusak lahan perkebunan dalam jumlah besar, namun tidak ada korban jiwa.

Cara mengusir satwa yang dipilih oleh responden di tiga desa sampel adalah mengusir dan menjaga kebun (68,4\%), mengusir dengan tembakan $(11,8 \%)$, menjerat
$(6,2 \%)$, menyetrum $(29,2 \%)$ dan meracun $(1,5 \%)$. Mengusir satwa dengan cara diracun hanya dilakukan oleh responden yang berada di Desa Gajah Mati. Berdasarkan wawancara dengan responden masyarakat, konflik gajah di daerah mereka relatif sering terjadi dan menjadi hal yang biasa. Masyarakat cenderung pasrah dan hanya melakukan pengusiran saat kedatangan gajah dan secara bergantian menjaga ladang pertanian dan kebun mereka untuk mengurangi kerugian yang dialami. Nuryasin et al., (2014), menyatakan upaya yang biasa dilakukan masyarakat dalam mengurangi gangguan satwa liar yaitu dengan menggunakan kawat listrik, bunyi-bunyian maupun penghalauan, namun upaya ini dapat mengakibatkan kematian maupun cacat fisik bagi satwa. Untuk mengatasi gangguan satwa liar dapat dilakukan dengan pendekatan berupa tindakan pemecahan masalah, baik untuk jangka pendek maupun jangka panjang. Tindakan pemecahan masalah jangka pendek bertujuan untuk mengatasi gangguan, biasanya dilakukan dengan menggunakan pemagaran, pembuatan parit, penggiringan, atau pemindahan. Pemecahan masalah jangka panjang harus dimulai dengan penelitian yang komprehensif, sehingga dapat disusun program pengelolaan yang tepat, misalnya dimulai dengan penataan daerah/habitat satwa liar, penetapan daya dukung dan jumlah satwa liar target yang harus dilestarikan, serta relokasi tempat-tempat penyebaran beserta penetapan populasi yang dipertahankan (Alikodra, 2010).

Tingginya tingkat gangguan gajah yang dialami petani dan tidak adanya pendampingan dan sosialisasi dari pihak terkait (perusahaan perkebunan, kehutanan dan kelompok masyarakat desa) menjadikan masyarakat memiliki persepsi dan pemahaman yang negatif terhadap kehadiran gajah. Garsetiasih (2015) menyatakan bahwa persepsi masyarakat terhadap sumber daya hutan berhubungan dengan tingkat pendidikan dan tidak adanya sosialisasi dari pengelola atau pihak yang berwenang. 
2. Persepsi responden terhadap manfaat kawasan hutan

Berdasarkan hasil wawancara dengan responden masyarakat di tiga desa yaitu Desa Gajah Mati, Desa Gajah Mukti dan Desa Gajah Mulya, diketahui bahwa manfaat kawasan hutan bagi sebagian besar masyarakat di tiga desa tersebut adalah sebagai tempat untuk mencari kayu gelam, kayu bakar, dan ladang pekerjaan. Persentase tertinggi persepsi masyarakat terhadap manfaat kawasan hutan yaitu sebagai tempat mencari kayu gelam adalah di Desa Gajah Mulya (52,9\%), sebagai tempat mencari kayu bakar di Desa Gajah Mukti (15,8\%), sebagai ladang pekerjaan bagi masyarakat di Desa Gajah Mati (24,5\%). Hanya sebagian kecil responden yang menyatakan bahwa manfaat kawasan hutan dapat menjadi tempat bagi perlindungan satwa (10,5\%), penghijauan $(10,5 \%)$, perlindungan air $(11,8 \%)$, dan penghasil oksigen (5,9\%) (Gambar 2). Hamid et al., (2011), menyatakan bahwa keberadaan masyarakat sekitar hutan merupakan bagian yang tidak terpisahkan dalam pengelolaan sumber daya hutan. Menurut Triyanto (2009), masyarakat yang tinggal di pinggiran hutan menganggap hutan memiliki fungsi sebagai tempat penyangga seluruh aspek kehidupan sosial, ekonomi dan budaya mereka. Dari hutanlah mereka memeroleh kayu bakar, obatobatan, buah-buahan, dan bahkan binatang buruan. Di samping itu, bagi penduduk desa pinggiran hutan, hutan merupakan cadangan bagi mereka ketika desa mereka tidak mampu lagi menyediakan lahan pertanian apabila terjadi pertambahan penduduk.

Pandangan atau persepsi masyarakat terhadap hutan, besar pengaruhnya pada bentuk hubungan manusia dengan hutan, yang dapat dibedakan menjadi seseorang menolak lingkungannya dan seseorang yang bekerja sama dan mengurus lingkungannya (mengekploitasi). Seseorang menolak

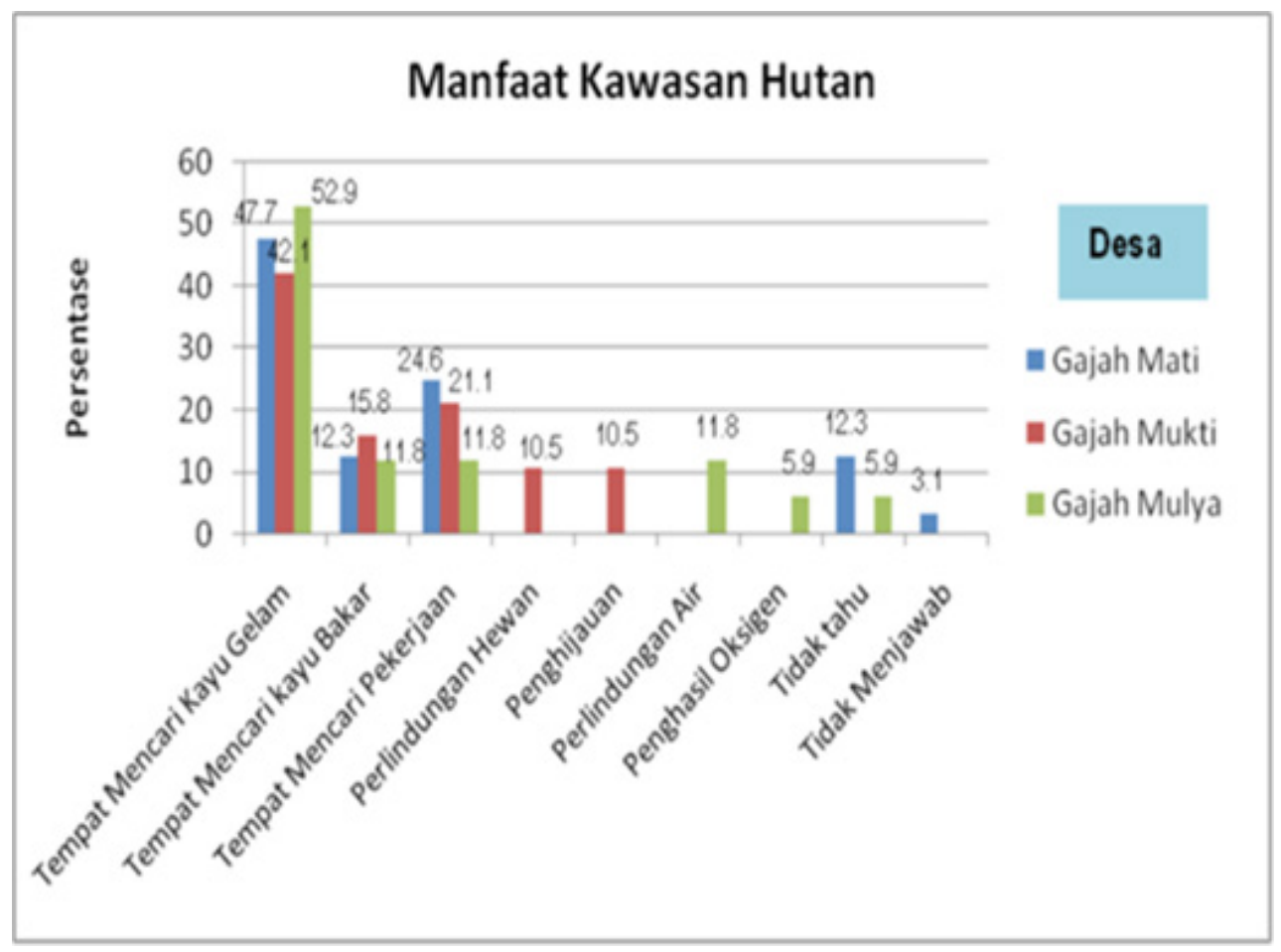

Sumber (Source): Data primer (Primary data)

Gambar 2. Persepsi masyarakat terhadap manfaat kawasan hutan Figure 2. Community perception to benefit of forest 
lingkungan disebabkan karena mempunyai pandangan yang tidak sesuai dengan apa yang diinginkannya, sehingga dapat memberikan bentuk tindakan terhadap hutan sesuai dengan apa yang dikehendakinya. Sebaliknya bagi yang mempunyai persepsi menerima lingkungan, seseorang tersebut biasanya lebih dapat memanfaatkan hutan sekaligus menjaga dan menyelamatkan hutan dari kerusakan, sehingga hutan memberi manfaat yang berkelanjutan. Dengan demikian lingkungan akan terjaga dari kerusakan dan memberikan manfaat bagi masyarakat sekitar (Junianto, 2007).

3. Persepsi responden terhadap manfaat gajah dan kawasan perkebunan

Pandangan atau persepsi masyarakat terhadap keberadaan gajah cenderung negatif. Dari hasil penelitian menunjukkan bahwa sebagian besar responden menyatakan gajah merupakan hewan yang merugikan $(68,4 \%)$, hewan yang merusak $(17,6 \%)$, dan sisanya $(10,5 \%)$ menganggap gajah hewan yang tidak bermanfaat (Gambar 3).

Dari semua responden yang diwawancarai terdapat responden yang menyatakan tidak tahu manfaat gajah bagi mereka. Responden

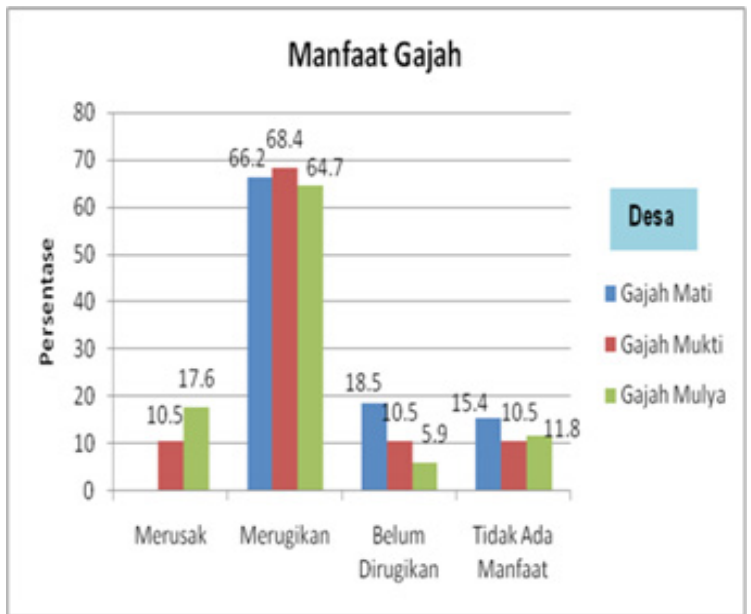

yang menyatakan tidak tahu sebenarnya sama persepsinya dengan yang menyatakan gajah tidak bermanfaat, mereka menganggap keberadaan gajah menimbulkan kerugian. Hanya sebagian kecil responden yang menyatakan belum merasa dirugikan oleh kehadiran gajah (5,9\%), dikarenakan ladang mereka belum pernah diganggu oleh gajah. Selain mempunyai persepsi yang negatif terhadap keberadaan gajah, responden juga menyatakan keberadaan perkebunan belum memberikan manfaat bagi masyarakat sekitar. Responden masyarakat di Desa Gajah Mati $(49,2 \%)$ menyatakan sangat mengharapkan diikutsertakan dalam kegiatan perkebunan seperti menjadi buruh perkebunan khususnya pada saat tidak berkegiatan di ladang atau saat musim kemarau. Responden di Desa Gajah Mulya menyatakan bahwa kawasan perkebunan belum memberikan manfaat bagi masyarakat sekitar (47,1\%). Responden menyatakan manfaat yang diharapkan dari perkebunan adalah adanya pemberian bantuan bibit tanaman dan pupuk dalam bentuk plasma $(32,6 \%)$ dan bantuan perbaikan jalan $(26,3 \%)$. Menurut Lesmana, Ratina, \& Jumriani (2011), tujuan masyarakat menjadi petani plasma mandiri kelapa sawit untuk meningkatkan

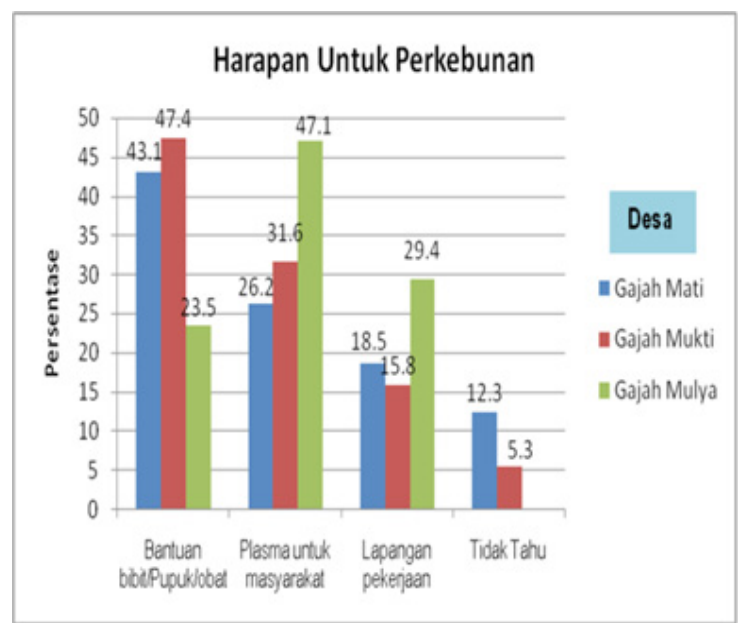

Sumber (Source): Data primer (Primary data)

Gambar 3. Persepsi masyarakat terhadap manfaat gajah dan perkebunan

Figure 3. Communtiy perception to benefit of elephant and plantation area 
pendapatan usahatani. Namun, berdasarkan wawancara dengan responden, diketahui bahwa perusahaan perkebunan belum melakukan program plasma secara optimal. Salah satu penyebab belum berjalannya program petani plasma karena beberapa perusahaan perkebunan yang ada di sekitar lokasi responden belum dapat melakukan optimalisasi penggunaan lahan yang dimiliki, sehingga belum mampu melakukan program plasma tersebut.

4. Persepsi responden terhadap pengelolaan konservasi gajah sumatera

Sebagian besar responden menyatakan bahwa mereka tahu bahwa gajah adalah satwa yang dilindungi, tetapi tidak tahu tujuan dari melindungi gajah. Responden menginginkan gajah dipindahkan dari kawasan hutan dan areal ladang yang mereka usahakan, karena masyarakat merasa terganggu oleh gajah, hal ini ditunjukkan oleh surat dari kepala desa yang ditujukan pada pemerintah daerah setempat atas gangguan gajah yang terjadi. Responden menyatakan gajah sebaiknya dipindahkan ke wilayah Suaka Margasatwa (SM) Padang
Sugihan. Persentase tertinggi sampai terendah responden yang menyatakan gajah sebaiknya dipindahkan ke SM Padang Sugihan adalah di Desa Gajah Mukti (84,2\%), Desa Gajah Mulya (82,4\%) dan Desa Gajah Mati (73,8\%) (Gambar 4). Tingginya persentase tersebut berkorelasi dengan tingkat gangguan, Desa Gajah Mukti merupakan desa yang mendapat gangguan gajah paling tinggi terutama pada saat-saat menjelang panen.

Responden menginginkan gajah dipindahkan karena gajah mengganggu ladang pertanian dan perkebunan masyarakat setiap menjelang musim panen dan musim kering. Selain itu, mereka menganggap bahwa SM Padang Sugihan merupakan habitat yang tepat bagi kelangsungan hidup gajah, baik dari aspek pakan, lingkungan, dan historis. Namun menurut Nuryasin et al., (2014), upaya pemindahan gajah dari lokasi satu ke lokasi lain dapat memungkinkan munculnya konflik baru di lokasi dimana gajah dipindahkan, mengingat gajah adalah satwa dengan daerah jelajah yang sangat luas dan termasuk satwa yang memiliki adaptasi yang lama. Pemindahan gajah bukanlah hal yang mudah

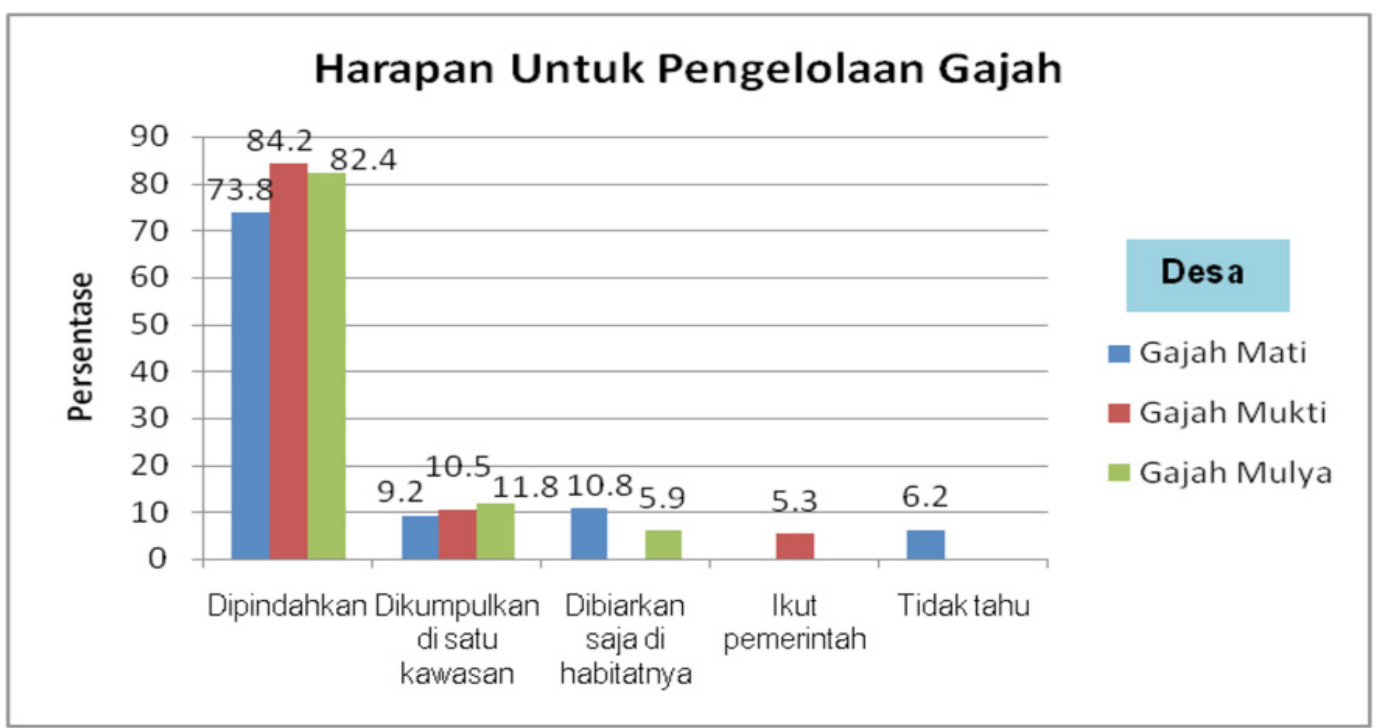

Sumber (Source): Data primer (Primary data)

Gambar 4.Pandangan masyarakat terhadap pengelolaan gajah di Desa Gajah Mati, Desa Gajah Mukti, dan Desa Gajah Mulya.

Figure 4. Community opinion to management of elephant in Gajah Mati, Gajah Mukti and Gajah Mulya Villages 
untuk dilakukan, selain membutuhkan tenaga ahli, karena khawatir terjadi kematian saat dilakukan pemindahan juga membutuhkan biaya operasional yang sangat besar.

Upaya konservasi dan kebijakan yang akan diambil dalam pengelolaan keanekaragaman hayati di suatu kawasan termasuk gajah perlu disosialisasikan kepada masyarakat khususnya masyarakat sekitar hutan dimana lokasi tinggalnya juga merupakan habitat gajah. Hal ini untuk meningkatkan pengetahuan dan kepedulian masyarakat terhadap keberlanjutan keanekaragaman hayati. Hilmayanti (2016) menyatakan bahwa pembentukan dasar konservasi harus disosialisasikan dengan baik kepada masyarakat dan bila sebagian besar masyarakat dapat mendukung tujuan pengelolaan serta bersedia dalam memenuhi peraturan bersama, maka kawasan tersebut akan mempunyai peluang yang lebih baik untuk mempertahankan komunitas hayatinya.

\section{KESIMPULAN DAN SARAN}

\section{A. Kesimpulan}

Tingkat pendidikan masyarakat berkorelasi dengan persepsi tentang upaya konservasi, khususnya jenis hewan gajah. Di lokasi penelitian, tingkat pendidikan yang rendah mendorong responden untuk memiliki persepsi negatif tentang upaya konservasi gajah. Gangguan gajah terdapat di semua desa responden, terutama merusak ladang dan kebun masyarakat yang mengakibatkan kerugian secara ekonomi. Responden menyatakan bahwa gajah tidak bermanfaat, hal ini dikhawatirkan akan berdampak pada keterancaman populasi gajah.

\section{B. Saran}

Untuk membangun persepsi yang positif terhadap konservasi gajah sumatera (Elephas maximus sumatranus Temminck, 1847) diperlukan penyuluhan, sosialisasi dan pelatihan tentang pentingnya mendukung program konservasi gajah, karena gajah berperan penting dalam menjaga keberlangsungan ekosistem. Perlu dilakukan pembinaan habitat untuk ketersediaan pakan di sekitar kawasan hutan yang berbatasan dengan perkebunan, sehingga gangguan gajah terhadap kebun masyarakat dan perusahaan perkebunan dapat diminimalisir.

\section{UCAPAN TERIMA KASIH (ACKNOWLEDGEMENT)}

Penulis mengucapkan terima kasih atas dukungan dan kerja sama dari PT. Sampoerna Agro Tbk. area Sumatera Selatan, PT. Selatan Jaya Permai dan PT. Sawit Selatan, PT. Bumi Mekar Hijau, PT. Russelindo Prima Putra, dan Balai Konservasi Sumber Daya Alam (BKSDA) Sumatera Selatan selama penelitian dilakukan.

\section{DAFTAR PUSTAKA}

Abdullah. (2009). Penggunaan habitat dan sumber daya oleh gajah sumatera (Elephas maximus sumatranus Temminck 1847) di hutan Provinsi Nangroe Aceh Darussalam menggunakan teknik GIS. Jurnal Berkala Penelitian Hayati Edisi Khusus, 3B, 47-54.

Alikodra, H.S. (1987). Manfaat taman nasional bagi masyarakat di sekitarnya. Media Konservasi, 1(3), 13-20.

Alikodra, H.S. (1990). Pengelolaan satwa liar. Jilid 1. Bogor: Pusat Antar Universitas Ilmu Hayati, Institut Pertanian Bogor.

Alikodra, H. (2010). Teknik pengelolaan satwa liar dalam rangka mempertahankan keanekaragaman hayati Indonesia. Bogor: Institut Pertanian Bogor Press.

Awang, S.A. (2006). Sosiologi pengetahuan deforestasi, konstruksi sosial dan perlawanan. Yogyakarta: Debut Press.

Badan Pusat Statistik. (2014). Kabupaten Ogan Komering Ilir dalam angka. Kabupaten OKI: Badan Pusat Statistik.

Berliani, K., Alikodra, H.S., Masy'ud, B., \& Kusrini, M.D. (2016a). Susceptibility of cultivated plants to sumatran elephant (Elephas maximus sumatranus) in the human elephants conflict in Aceh Province. Jurnal Manajemen Hutan Tropika, 22(1), 65-74. 
Berliani, K., Alikodra, H.S., Masy'ud, B., \& Kusrini, M.D. (2016b). Social, economy, cultural and community perception on sumatran elephant (Elephas maximus sumatranus) conflict area in Aceh Province. International Journal of Sciences: Basic and Applied Research, 27(2), 170-181.

Berliani, K., Alikodra, H.S., Masy'ud, B., \& Kusrini, M.D. (2016c). Aktivitas makan pada gajah sumatera (Elephas maximus sumatranus) terhadap kerentanan budidaya pertanian di Provinsi Aceh (pp. 48-61). Prosiding Seminar Nasional Biologi: Implementasi Riset Hayati dan Pengembangannya di Era Masyarakat Ekonomi ASEAN, Medan, 6 April 2016. Medan: USU Press.

Chen, J., Deng, X., Zhang, L., \& Bai, Z. (2006). Diet composition and foraging ecology of asian elephants in Shangyong Xishuangbanna, China. Acta Ecologica Sinica, 26(2), 309-316.

Febriani, R. (2009). Pemetaan daerah rawan konflik gajah menggunakan sistem informasi geografis di Taman Nasional Gunung Leuser. (Skripsi). Medan: Fakultas Pertanian. Universitas Sumatera Utara.

Garsetiasih, R. (2012). Manajemen konflik konservasi banteng (Bos javanicus d'Alton, 1832) dengan masyarakat di Taman Nasional Meru Betiri dan Taman Nasional Alas Purwo Jawa Timur. (Disertasi). Bogor: Institut Pertanian Bogor.

Garsetiasih, R. (2015). Persepsi masyarakat sekitar kawasan Taman Nasional Meru Betiri dan Taman Nasional Alas Purwo yang terganggu satwa liar terhadap konservasi banteng (Bos javanicus d'Alton 1832). Jurnal Penelitian Hutan dan Konservasi Alam, 12(2), 119-135.

Garsetiasih, R., Rianti, A., \& Eman. (2015). Status dan resolusi konflik gajah-manusia di Sumatera. (Laporan Hasil Penelitian). Bogor: Pusat Penelitian dan Pengembangan Hutan Bogor (unpublished).

Hamid, A. (2001). Mengenal lebih dekat gajah sumatera di Ekosistem Leuser. Buletin Leuser, 4(11).

Hamid, R., Zulkarnaini, \& Saam, Z. (2011). Analisis sosial ekonomi masyarakat desa hutan pasca kegiatan HPH PT. Siak Raya Timber di Kabupaten Pelalawan, Provinsi Riau. Jurnal Ilmu Lingkungan, 5(2), 130-148.

Harahap, W.H., Pratana, P., \& Afifuddin, Y. (2012). Mitigasi konflik satwa liar dengan masyarakat di sekitar Taman Nasional Gunung Leuser (Studi kasus Desa Timbang Lawan dan Timbang Jaya Kecamatan Bahorok Kabupaten Langkat). (Laporan Hasil Penelitian). Medan: Fakultas
Pertanian. Universitas Sumatera Utara.

Hariyanto, M. (2010). Penanggulangan konflik antara manusia dan satwa liar. Diunduh 13 Oktober 2016 dari http://blogmhariyanto.blogspot. com/2010/07/penanggulangan-konflik-antaramanusia.html.

Hedges, S., Tyson, M., Sitompul, A., Gunaryadi, D., Aslan, \& Kinnaird, M. (2002). Sumatran elephant population survey in Lampung Province, Sumatera, Indonesia. (A Report to The National Geographic Society). Bogor: WCS Sumatran Elephant Project.

Hilmayanti, P. (2016). Persepsi masyarakat sekitar kawasan konflik gajah-manusia terhadap konservasi gajah dan habitatnya di Kecamatan Lembah Seulawah Kabupaten Aceh Besar. (Skripsi). Banda Aceh: Program Studi Pendidikan Biologi FKIP. Universitas Syiah Kuala.

International Union for The Conservation of Nature (IUCN). (2011). Elephas maximus ssp. sumatranus. Diunduh 19 Mei 2017 dari http:// www.iucnredlist.org/details/199856/0.

Jogasara, F. (2011). Analisis faktor-faktor yang memengaruhi intensitas konflik antara gajah dengan manusia di Kecamatan Mandau dan Kecamatan Pinggir Kabupaten Bengkalis. (Thesis). Pekanbaru: Program Pasca Sarjana Fakultas Pertanian. Universitas Riau.

Junianto, B. (2007). Persepsi, sikap dan perilaku masyarakat sekitar terhadap keberadaan Hutan Penelitian Haurbentes (Studi kasus di Desa Jugulaya, RPH Jasinga, BKPH Jasinga). (Skripsi). Bogor: Institut Pertanian Bogor.

Kadir, A. (2005). Pengembangan sosial forestry di SPUC Barisallo: Analisis sosial ekonomi dan budaya masyarakat. Info Sosial Ekonomi (5)3, 297-309.

Kadir, A., Awang, S.A., Purwanti, R. H., \& Poedjirahajoe, E. (2012). Analisis kondisi sosial ekonomi masyarakat sekitar Taman Nasional Bantimurung Bulusaraung, Provinsi Sulawesi Selatan. Jurnal Manusia dan Lingkungan, 19 (1), 1-11.

Kadir, A., Nurhaedah, \& Purwanti, R. (2013). Konflik pada kawasan Taman Nasional Bantimurung Bulusaraung Provinsi Sulawesi Selatan dan upaya penyelesaiannya. Jurnal Penelitian Sosial dan Ekonomi Kehutanan, 10(3), 186198.

Lesmana, D., Ratina, R., \& Jumriani. (2011). Hubungan persepsi dan faktor-faktor sosial ekonomi terhadap keputusan petani mengembangkan pola kemitraan petani plasma mandiri kelapa 
sawit (Elaeis guineensis Jacq) di Kelurahan Bantuas Kecamatan Palaran Kota Samarinda. Jurnal Ekonomi Pertanian dan Pembangunan (EPP), 8(2), 8-17.

Mursidah. (2009). Optimalisasi pendapatan usahatani kelapa sawit. Jurnal Ekonomi Pertanian dan Pembangunan (EPP), 6(2), 8-17.

Nurlita, I.W., \& Mamonto, R. (2012). Persepsi masyarakat terhadap taman nasional dan sumber daya hutan: Studi kasus blok Aketajawe Taman Nasional Aketajawe Lolobata. Info Balai Penelitian Kehutanan Manado, 2(1), 1-15.

Nurrani, L., \& Tabba, S. (2013). Persepsi dan tingkat ketergantungan masyarakat terhadap sumber daya alam Taman Nasional Aketajawe Lolobata di Provinsi Maluku Utara. Jurnal Penelitian Sosial dan Ekonomi Kehutanan, 10(1), 61-73.

Nuryasin, Yoza, D., \& Kausar. (2014). Dinamika dan resolusi konflik gajah sumatera (Elephas maximus sumatranus) terhadap manusia di Kecamatan Mandau Kabupaten Bengkalis, Riau. Jom Faperta, 1(2), 119-127.

PT Sampoerna Agro. (2013). Rapat pembahasan penyebab konflik gajah-manusia antara Direktur Konservasi Keanekaragaman Hayati, Dirjen KSDAE KLHK dengan perusahaan perkebunan PT. Sampoerna Agro, Tbk. Rapat Koordinasi, Jakarta 14 November 2013.

Riba'i, Setiawan, A., \& Darmawan, A. (2013). Perilaku makan gajah sumatera (Elephas maximus sumatranus Temminck 1847) di Pusat Konservasi Gajah Taman Nasional Way Kambas. Media Konservasi, 18(2), 89-95.

Rifa'i, A., Hadi, S., \& Qomar, N. (2008). Studi pengembangan kelapa sawit rakyat di Provinsi Riau. Jurnal Sagu, 7(2), 1-6.

Saleh, C., \& Adriani. (2005). Petualangan ghazu, gajah sumatera. Jakarta: WWF Indonesia.

Seidenticker, J. (1984). Managing elephants depredation in agricultural and forestry projects, World Bank Technical Paper. (ISSN 0153 - 7494). Washington, D.C: The World Bank.

Suhandri, W., Sukamtoro, Samsuardi, H., Rusiano, \& Yulianto, K. (2011). Analisis konservasi gajah sumatera di Kantong Balai Raja (Blok Ribo)
Kabupaten Bengkalis, Propinsi Riau. Jurnal WWF Indonesia dan BBKSDA Propinsi Riau, 5, 3-4.

Suhartono, T., Susilo H.D., Sitompul, A.F., Gunaryadi D., Purastuti E.M., Azmi W, Fadhil N., \& Stremme C. (2007). Strategi dan rencana aksi konservasi gajah sumatera dan gajah kalimantan 2007-2017. Jakarta: Direktorat Jenderal Perlindungan Hutan dan Konservasi Alam, Departemen Kehutanan.

Sukumar, R. (1989). The asian elephant ecology and management. Cambridge UK: 'Cambridge University Press.

Syarifuddin, H. (2008). Analisis daya dukung habitat dan pemodelan dinamika gajah sumatera: Studi Kasus di Kawasan Seblat Kabupaten Bengkulu Utara. (Disertasi Pascasarjana). Bogor: Institut Pertanian Bogor.

Triyanto, D. H. (2009). Persepsi, motivasi, sikap dan perilaku masyarakat lokal terhadap keberadaan hutan (Kasus di Kecamatan Gunung Kencana, Kabupaten Lebak, Provinsi Banten). (Skripsi). Bogor: Institut Pertanian Bogor.

Unit KSDA Riau. (2010). Upaya pelestarian Gajah di Provinsi Riau. (Laporan Kegiatan). Pekanbaru: Dinas Kehutanan Provinsi Riau..

World Wildlife Fund (WWF) \& Balai KSDA Provinsi Riau. (2010). Protokol pengurangan konflik gajah sumatera di Riau. (Laporan Kerja Sama Penelitian). Pekanbaru: World Wildlife Fund (WWF) \& Balai KSDA Provinsi Riau.

Wulan, Y.C., Yasmi, Y., Purba C., \&Wollenberg, E. (2004). Analisa konflik sektor kehutanan di Indonesia 1997-2003. Bogor: Center for International Forestry Research (CIFOR).

Yoza, D. (2003). Inventarisasi, identifikasi dan keanekaragaman jenis satwa liar di Tahura SSH. (Laporan Penelitian Bekerja Sama dengan Dinas Kehutanan Propinsi Riau). Pekanbaru: Dinas Kehutanan Provinsi Riau.

Yoza, D. (2009). Pemetaan sebaran gajah di areal konsesi PT. Chevron Pacific Indonesia. (Laporan Penelitian Bekerja Sama dengan PT. Chevron Pacific Indonesia, Riau). Pekanbaru: PT Chevron Pacific Indonesia. 